\title{
A TAXONOMY OF CONSTITUTIONAL ARGUMENTS
}

(2014) 35 Statute Law Review 211-229

\section{Po Jen Yap ${ }^{\dagger}$}

Abstract: This article explores how the Supreme Court of the United Kingdom (and the House of Lords) has generally appealed to four forms of constitutional arguments when interpreting the Human Rights Act 1998: (i) textual arguments, (ii) historical arguments, (iii) precedential arguments, and (iv) consequentialist arguments. The author will also illustrate how the various types of constitutional arguments are substantially interdependent and interrelated, such that they often dovetail with one another to reach a reasonably coherent and defensible legal result.

\section{INTRODUCTION}

The Human Rights Act 1998 (HRA) has been in force since 2000; and naturally, in view of this statutory development, we have witnessed in the last decade a burgeoning discourse on the record of the House of Lords and its succeeding body, the Supreme Court of the United Kingdom, on rights-adjudication. The academic debate has however focused primarily on three key areas: (i) the relationship between Strasbourg jurisprudence and English case law ${ }^{1}$, (ii) the interplay between the UK judiciary's interpretive mandate under section 3 of the HRA and its power to issue a declaration of incompatibility pursuant to section $4^{2}$, and (iii) the 'dialogic' nature of the HRA that facilitates a constitutional conversation between Parliament and the judiciary. ${ }^{3}$

Notwithstanding the plethora of academic literature on the HRA, there has been little discussion on the types of interpretive arguments the House of Lords and the Supreme Court of the United Kingdom (hereinafter termed collectively as the Court) deploy in reaching a particular legal result under the HRA. This lacuna in the literature is

\footnotetext{
${ }^{\dagger}$ The author is grateful for the excellent research assistance provided by Peter Dong, Gilbert Mok, and Sally Wong. All errors are the author's own. He can be contacted at pjyap@hku.hk

${ }^{1}$ See R Masterman 'Taking the Strasbourg Jurisprudence into Account: Developing a "municipal law of human rights" under the Human Rights Act' (2005) 54 ICLQ 907; J Wright 'Interpreting Section 2 of the Human Rights Act 1998: Towards an Indigenous Jurisprudence of Human Rights' [2009] PL 595; R Clayton 'Smoke and Mirrors: the Human Rights Act and the impact of Strasbourg case law' [2012] PL 639; M Amos 'The Dialogue between United Kingdom courts and the European Court of Human Rights' (2012) 61 ICLQ 557; B Dickson 'The Record of the House of Lords in Strasbourg' (2012) 128 LQR 354.

${ }^{2}$ See D Bonner, H Fennick and S Harris-Short 'Judicial Approaches to the Human Rights Act' (2003) 52 ICLQ 549; A Kavanagh 'The Elusive Divide between Interpretation and Legislation under the Human Rights Act 1998' (2004) 24 OJLS 259; J van Zyl Smit 'The New Purposive Interpretation of Statues: HRA Section 3 after Ghaidan v Godin - Mendoza' (2007) 70 MLR 294.

${ }^{3}$ See R Clayton 'Judicial Deference and 'Democratic Dialogue': the Legitimacy of Judicial Intervention under the Human Rights Act 1998' [2004] PL 33; T Hickman 'Constitutional Dialogue, Constitutional Theories and the Human Rights Act 1998' [2005] PL 306; D Nicol 'Law and Politics after the Human Rights Act' [2006] PL 722; A Young 'Is Dialogue Working under the Human Rights Act 1998?' [2011] PL 773 .
} 
especially surprising, since the most common and central task of the courts under the HRA is to always construct, in each case, the constitutional arguments in favour of, or against, a particular result by appealing to a range of interpretive methods available and appropriate under the law. This article will thus seek to fill the gap in the literature by exploring how the Court has generally appealed to four constitutional 'modalities' ${ }^{4}$ when interpreting the HRA: (i) textual arguments, (ii) historical arguments, (iii) precedential arguments, and (iv) consequentialist arguments.

Textual arguments are constitutional arguments that focus on the statutory language of the HRA; such interpretive arguments examine the meaning of the statutory text, as situated within the linguistic practice of the community, alongside the accepted canons of statutory interpretation. Historical arguments ${ }^{5}$ appeal to the original understandings of the framers of the HRA when they were seeking to incorporate the European Convention of Human Rights (hereinafter referred to as the Convention) within domestic law. Arguments from precedent seek to construct from prior caselaw, for example decisions of the European Court of Human Rights (ECHR) or House of Lords, persuasive authority for how the current dispute should be resolved, by arguing how those past decisions and the propositions of law advanced therein are on point or analogous to the present one. Finally, consequentialist arguments seek to reach legal answers from a calculus of costs and benefits, when the facts are taken into account. ${ }^{6}$ They usually involve the application of a 'balancing' test that seeks to weigh the value of competing rights and interests. Furthermore, this consequentialist 'balancing' test also takes into the institutional disadvantages of the judicial forum and the conditions of epistemic uncertainty that judges face during adjudication, and this explains the role of judicial deference when courts engage in such consequentialist argumentation. However, one must note at the outset that there is no formal hierarchy of constitutional arguments that the Court has deployed; different types of interpretive arguments are more appropriate and persuasive when different clauses of the HRA are operative.

The classification of constitutional argumentation in general is not new. Professor Phillip Bobbitt in a seminal book was the first to devise a typography of constitutional arguments. With regard to the US constitution, he describes six such forms that

\footnotetext{
${ }^{4}$ Philip Bobbitt has in Constitutional Fate: Theory of the Constitution (New York: Oxford University Press 1st edn, 1984) argued, within the US constitutional system, that there are six particular forms of constitutional arguments, which he terms 'modalities'. These six 'modalities' operative in the American constitutional system are (i) historical, (ii) textual, (iii) structural, (iv) ethical, (v) doctrinal, and (vi) prudential.

${ }^{5}$ Originalism, a fashionable constitutional theory in the United States, is an extreme example/variant of the historical argument, i.e. for strict originalists, a constitutional instrument can only be interpreted in light of the original understanding of those who wrote and ratified the relevant language, and the public understanding of those terms at the specified historical periods in time. See Bork The Tempting of America: The Political Seduction of the Law (New York: Free Press, 1990) pp 144-155; A Scalia 'Common Law Courts in a Civil Law System: The Role of the United States Federal Courts in Interpreting the Constitution and Laws' in A Gutmann (ed) A Matter of Interpretation (Princeton, NJ: Princeton University Press, 1998) $\mathrm{p}$ 17. On the other hand, while courts in practice view historical arguments/sources as important, they rarely consider such arguments determinative in constitutional adjudication, as originalists do.

${ }^{6}$ P Bobbitt Constitutional Interpretation (Oxford: Blackwell, 1st edn, 1991) p 17.
} 
constitute the justificatory matrix of American constitutional law: (i) the historical (relying on the intentions of the framers and the ratifiers of the constitution); (ii) textual (looking to the meaning of the word of the constitution alone as understood by the reasonable person); (iii) structural (inferring rules from the relationships that the constitution mandates among the structures it sets up); (iv) doctrinal (applying rules generated by precedent); (iv) ethical (deriving rules from those moral commitments/ethos that are reflected in the constitution); and (v) prudential (seeking to balance the costs and benefits of a particular rule). ${ }^{7}$

Understandably, my readers may ask whether this constitutional method as devised by an American vis-à-vis the US constitution is applicable to the United Kingdom. Put it another way, can a British Bill of Rights be read in the same way as an American constitutional instrument, with a history of over two centuries, which has been interpreted almost without the influence of any Convention law? This is an important methodological objection to which I will now address.

First, this objection may have conflated the issue of constitutional substance with its form. The above methodological objection is essentially a concern over the substance of constitutional law, that is, different countries with different histories may draft different texts to address different problems, such that a constitutional decision reached by a national court in one case may not be applicable if the same issue arises in a different jurisdiction. But Bobbitt was not providing a constitutional theory to prescribe the substance of constitutional law in America or in any other jurisdiction. Instead, he had developed a set of constitutional grammar for constitutional discourse. These forms of arguments do not prescribe the substantive result that any judge would reach, any more than the rules of grammar would dictate the substance of what we say. In other words, these forms of constitutional argumentation are the tools of the judicial trade; they do not, in themselves, determine what the judges build with them. Therefore, any concern that American law is untethered to ECHR jurisprudence is irrelevant to the issue that I am examining herein, which is the form of constitutional argumentation and not the substance of constitutional decisions.

Secondly, my readers may respond by querying whether the forms of constitutional grammar applicable in the United States differ from that used in the United Kingdom. Indeed, they are not wholly the same; hence my taxonomy differs in part from that of Bobbitt's. The consequentialist argument deployed by the Court is wider than the prudential 'cost-benefit analysis' argument applied in the United States. Furthermore, structural and ethical arguments have not been deployed by the Court vis-à-vis HRA adjudication. This is not to say that they will never be, as the Court can adopt such forms of argumentation in future cases. These four categories of mine are not meantto be exhaustive and complete for all times; they merely reflect the current state of Britain's development. Indeed, the judicial use of ethical arguments as championed by common law constitutionalists ${ }^{8}$ may emerge in the future vis-à-vis the HRA

\footnotetext{
${ }^{7}$ Ibid, pp 12-13.

${ }^{8}$ See Poole 'Back to the Future? Unearthing the Theory of Common Law Constitutionalism' (2003) OJLS 435.
} 
adjudication.

Therefore, the normative attraction of Bobbitt's theory is that its general applicability is not strictly confined to the unique state of American constitutional review; so long as any of these forms of argumentation are practised by the Court in the United Kingdom, and accepted so by its community, they are legitimate forms of authority in Britain too. In other words, the constitutional forms of argumentation are legitimate tools of interpretation precisely because we can locate them within Britain's constitutional discourse.

Therefore, the thrust of this project will be to illustrate how the actual constitutional practice of the Court currently reflects this four-fold 'multi-valenced" interpretive model of interpretation. In so doing, I shall also endeavour to show how this pluralistic interpretive model is normatively attractive as a constitutional theory as it 'fits' the central features of Britain's constitutional practice and is also superior to the alternatives. $^{10}$

Part 1 of this paper begins by elaborating upon and fleshing out the abovementioned types of constitutional arguments, and illustrating how the Law Lords have deployed these arguments when adjudicating over HRA claims. Naturally, in the limited space one has, I have only chosen to discuss the HRA cases of the Court that are most illustrative of my central arguments; but it is my considered view that the Court has deployed one or more of the modalities discussed in every HRA case decided. Part 2 of the paper continues by defending the normative value associated with this 'multivalenced' interpretive model. To do so, I shall concede, at the outset, that this model can never provide a single correct answer in every instance. But neither can any constitutional theory rely upon any one particular unitary interpretive methodology (whether that exclusive source may be the text, history, or precedents of the HRA) to resolve a concrete dispute. After all, even within each modality or type of constitutional argument, there may still be 'intra-modal' ${ }^{11}$ conflicts, such that there can still be reasonable disagreements as to what the correct answer within that modality is. My more modest aim, in Part 2, is to illustrate how the various types of constitutional arguments are substantially interdependent and interrelated, such that they often dovetail with one another to reach a reasonably coherent and defensible legal result.

\section{PART 1: THE TAXONOMY}

\section{(a) Textual Arguments}

Textual arguments are constitutional arguments that focus on the statutory language of the HRA. Specifically, one may observe both internal and external constraints on the interpretation of text. Internal constraints on text are imposed by the reciprocal

\footnotetext{
${ }^{9}$ V Jackson 'Multi-Valenced Constitutional Interpretation and Constitutional Comparisons: An Essay in Honour of Mark Tushnet' (2008) Quinnipiac L.Rev. 599.

${ }^{10} \mathrm{R}$ Dworkin Law's Empire (London: Fontana Press, 1st edn, 1986) pp 397-399.

${ }^{11}$ See J Balkin and S Levinson 'Constitutional Grammar'(1994) 72 Texas L.Rev. 1771, 1796.
} 
interplay between a word and the sentence it is found within. ${ }^{12}$ Nevertheless, the meaning of a sentence is not entirely determined by the meanings of its parts and their syntactical combination in that sentence. ${ }^{13}$ In many instances, the 'literal' meaning of a sentence only has application and relevance relative to a set of external, contextual assumptions, common to the interpretive community, which cannot be fully realized by the semantic structure of the said sentence. ${ }^{14}$

The best example where the House of Lords has deployed textual arguments in HRA adjudication would be $R$ v. Lambert. ${ }^{15}$ In that case, the Law Lords had to determine, inter alia, whether the HRA could apply retrospectively to appeals against convictions that were secured in trials that predated the coming into effect of the HRA. The key sections on retrospectivity under the HRA are laid out in section 22(4) read against section $7(1)$ (b). Specifically, section $7(1)$ (b) provides that a person who claims that a public authority has acted in an unlawful way may rely on the Convention right concerned in any legal proceedings, but according to section 22(4), section 7(1)(b) only 'applies to proceedings brought by or at the instigation of a public authority whenever the act in question took place; but otherwise that subsection does not apply to an act taking place before the coming into force of that section.'

According to the majority in Lambert, an appeal was not a proceeding within the scope of section 22(4) read with section $7(1)(\mathrm{b})$. This was because, pursuant to section $7(6)$ of the HRA, the term 'legal proceedings' in section 7(1)(b) includes: (i) proceedings brought by or at the instigation of a public authority and (ii) an appeal against the decision of a court. Since section 22(4) of the HRA refers only to proceedings, and not legal proceedings, and does not mention appeals, appeals therefore would not be covered by the retrospectivity statutory clause.

As opined by Lord Clyde:

[I]n terms of section 22(4) the only acts contravening the Convention prior to 2 October 2000 which can be considered are acts on which reliance may be placed in terms of section 7(1)(b). Section 22(4) states expressly that 'otherwise that subsection does not apply to an act taking place before the coming into force of that section'. That subsection applies to 'legal proceedings' as defined in section 7(6), that is, both 'proceedings brought by or at the instigation of a public authority' and an appeal. But the provision admitting reliance on earlier acts in section 22(4) is limited to 'proceedings brought by or at the instigation of a public authority'. The use of the same language as was used in section 7(6) is significant. In my view the intention is that section 22(4) should not extend to the other kind

\footnotetext{
${ }^{12}$ GH Taylor 'Structural Textualism' (1995) 75 Boston U.L. Rev. 321, 359.

13.

${ }^{13} \mathrm{~J}$ Searle 'The Background of Meaning' in J Searle et al . (eds) Speech Act Theory and Pragmatics (Dordrecht, Holland: D. Reidel, 1980) pp 221, 223.

14 J Searle 'Literal Meaning' (1978) 13 Erkenntnis 207, 210.

${ }^{15}$ [2002] 2 AC 545 (HL).
} 
of 'legal proceedings' mentioned in section 7(6), namely an appeal. ${ }^{16}$

This textual construction of section 22(4) was also echoed by the other Law Lords in the Lambert majority. ${ }^{17}$ Therefore, where the retrospectivity clause refers, in identical words to the words found in section 7(6)(a), that is, "proceedings brought by or at the instigation of a public authority', the retrospective operation permitted by section 22(4) would therefore not apply to an appeal against a judicial decision.

Textual arguments were equally deployed by Lord Rodger in $R$ (Al-Skeini \& others) v. Secretary of State for Defence. ${ }^{18}$ On the facts, the House of Lords had to decide whether the HRA applied to six Iraqi civilians who had been killed by or in the course of action taken by British soldiers in Iraq. ${ }^{19}$ Specifically, Lord Rodger wrote the leading judgment on whether the HRA applied to acts committed outside the territory of the United Kingdom. Section 6(1) of the HRA provides that it is unlawful for a public authority to act in a way which is incompatible with a Convention right. Furthermore, section 7(1) of the HRA states that a person who claims that public authority has acted unlawfully may bring proceedings against a public authority or rely on the Convention rights in any legal proceedings, but only if he is a victim of that unlawful act. Nevertheless, the Secretary of State had sought to argue that sections 6 and 7 should be interpreted to exclude acts performed, or producing effects, outside the United Kingdom. ${ }^{20}$ Lord Rodger, however, in affirming that the central purpose of the HRA was to provide a remedial structure in domestic law for Convention rights, rejected the Secretary of State's argument and observed as follows:

I am unable to accept that submission. It involves reading into sections 6 and 7 a qualification which the words do not contain and which runs counter to the central purpose of the Act. That would be to offend against the most elementary canons of statutory construction which indicate that, in case of doubt, the Act should be read so as to promote, not so as to defeat or impair, its central purpose. ${ }^{21}$

\section{(b) Historical Arguments}

Historical arguments are deployed when the Law Lords seek to identify the meaning

\footnotetext{
${ }^{16}$ Lambert (n 15) [140].

${ }^{17}$ Ibid [9] (Lord Slynn), [116] (Lord Hope), [172] (Lord Hutton). This textual reading of section 22(4) read against section 7(1)(b) of the HRA has been subjected to much criticism. See D Beyleveld, R Kirkham and D Townend 'Which Presumption? A Critique of the House of Lords' Reasoning on Retrospectivity and the Human Rights Act' (2002) 22 LS 185.

18 [2008] 1 AC 153.

19 A majority on the House of Lords held that the HRA could apply to acts done outside the territory of United Kingdom but, on the facts, five of the claimants were not within the jurisdictional control of the UK government when they were killed. On further appeal to the European Court of Human Rights, in $\mathrm{Al}$ Skeini v . United Kingdom (2011) 53 EHRR 18, the Grand Chamber held that all six Iraqi civilians were within United Kingdom's jurisdictional control when they were killed.

${ }^{20}$ Al-Skeini \& others (n 18) [56].

${ }^{21}$ Al-Skeini \& others (n 18) [57].
} 
of the statutory language in the HRA by discerning what the framers would have originally understood the provisions to mean when they were enacting the text as law. Such original understandings could be derived from legislative history such as the White Paper on the Human Rights Bill and/or records of the parliamentary statements made during the passage of the HRA.

An excellent illustration of how historical arguments were deployed would be Lord Steyn's judgment in $R$ v. $A^{22}$, where the House of Lords had to consider, inter alia, whether the section 3 interpretive obligation under the HRA could be used to read into a rape-shield legislation an implied provision that evidence which was required to ensure a fair trial under Article 6 of the Convention would not be treated as inadmissible. While Lord Steyn and counsel on both sides conceded that on ordinary methods of statutory interpretation, the impugned penal provision could not reasonably bear such a reading ${ }^{23}$, his Lordship opined that Parliament, when passing the HRA, had intended the section 3 interpretative obligation to apply differently and more radically:

The White Paper made clear that the obligation goes far beyond the rule which enabled the courts to take the Convention into account in resolving any ambiguity in a legislative provision: see 'Rights Brought Home: The Human Rights Bill' (1997) (Cm 3782), para 2.7. The draftsman of the Act had before him the slightly weaker model in section 6 of the New Zealand Bill of Rights Act 1990 but preferred stronger language. Parliament specifically rejected the legislative model of requiring a reasonable interpretation. Section 3 places a duty on the court to strive to find a possible interpretation compatible with Convention rights. Under ordinary methods of interpretation a court may depart from the language of the statute to avoid absurd consequences: section 3 goes much further...section 3 is more radical in its effect.... In the progress of the Bill through Parliament the Lord Chancellor observed that 'in 99\% of the cases that will arise, there will be no need for judicial declarations of incompatibility' and the Home Secretary said 'We expect that, in almost all cases, the courts will be able to interpret the legislation compatibility with the Convention': Hansard (HL Debates), 5 February 1998, col 840 (3rd Reading) and Hansard (HC Debates), 16 February 1998, col 778 (2nd Reading)...In accordance with the will of Parliament as reflected in section 3 it will sometimes be necessary to adopt an interpretation which linguistically may appear strained. ${ }^{24}$

Another good illustration of how historical arguments were harnessed in the context of the HRA adjudication would be Lord Rodger's dissenting opinion in the Attorney General's Reference (No 2 of 2001) ${ }^{25}$. In that case, the majority on the House of Lords held that a stay of criminal proceedings would be allowed where the accused

\footnotetext{
${ }^{22}$ [2002] 1 AC 45.

23 Ibid [43].

24 Ibid [44].

${ }^{25}$ [2004] 2 AC 72 (HL).
} 
had not been brought to trial within a reasonable time and a fair hearing was no longer possible or it was, for any compelling reason, unfair to now try the defendant. Specifically, Lord Bingham, who wrote the leading judgment for the majority, held that section 6 of the HRA only authorized the court to entertain proceedings against a defendant 'if to do so is compatible with the defendant's Convention rights and so lawful but not if to do so is incompatible with the defendant's Convention rights and so unlawful.'26

In disagreement, Lord Rodger, in turn, argued that section 6 had no bearing on how courts could fashion a just and appropriate remedy to address a breach of a Convention right and it merely existed to 'act as the key to unlock these remedies.' ${ }^{27}$ In support of this view, his Lordship cited the UK government's statements in the White Paper, Rights Brought Home: The Human Rights Bill ${ }^{28}$ :

A public authority which is found to have acted unlawfully by failing to comply with the Convention will not be exposed to criminal penalties. But the court or tribunal will be able to grant the injured person any remedy which is within its normal powers to grant and which it considers appropriate and just in the circumstances. What remedy is appropriate will of course depend both on the facts of the case and on a proper balance between the rights of the individual and the public interest. In some cases, the right course may be for the decision of the public authority in the particular case to be quashed. ${ }^{29}$

Therefore, according to Lord Rodger, the government, when commending the Human Rights Bill to Parliament, clearly did not intend for every unlawful act of a public authority, that was incompatible with the Convention, to be always quashed. Instead, the Bill was not intended to "prescribe any specific remedy for a violation... and would leave it to the courts to choose the appropriate remedy in the circumstances. ${ }^{30}$

\section{(c) Precedential Arguments}

Argumentation from precedent is a core structural feature of adjudication in the UK and across all common law systems. The doctrine of precedent is generally justified on the basis that it enhances the predictability in the law so far as the citizenry can expect courts to follow their prior case-law; and this in turn promotes fairness by ensuring that similarly situated litigants are treated equally before the law. ${ }^{31}$ Furthermore, the doctrine of stare decisis facilitates decisional efficiency ${ }^{32}$; where judges express epistemic humility to the wisdom to their predecessors, they are freed from reconsidering every issue before the court. As observed by the US

\footnotetext{
${ }^{26}$ Ibid [30].

${ }^{27}$ Ibid [171].

${ }^{28}$ The Home Department, Rights Brought Home: The Human Rights Bill (White Paper, Cm. 3782, 1997).

${ }^{29}$ Ibid, para 2.6.

${ }^{30}$ Attorney General's Reference (No 2 of 2001) (n 25) [172].

${ }^{31}$ E Maltz 'The Nature of Precedent' (1988) 66 N.C.L.Rev. 367, 369.

${ }^{32}$ F Schauer 'Precedent' (1987) 39 Stanford L.Rev. 571.
} 
Supreme Court Justice Benjamin Cardozo,

the labour of judges would be increased almost to the breaking point if every past decision could be reopened in every case, and one could not lay one's own course of bricks on the secure foundation of the courses laid by others who had gone before him. ${ }^{33}$

According to section 2 of the HRA, the UK judiciary must 'take into account' the case-law of the ECHR. As a matter of practice, the Court would follow any 'clear and constant jurisprudence, 34 of the ECHR, and has declined to follow Strasbourg when it perceives that the ECHR has not sufficiently appreciated and accommodated particular aspects of the UK domestic process. ${ }^{35}$ It is however outside the scope of this paper to fully explore whether or when the "mirror principle"36, that is, the domestic courts' interpretation of the HRA should seek to mirror the corresponding Convention rights, as interpreted by the ECHR, should apply in the United Kingdom; my purpose herein is to merely illustrate how the Court has deployed precedential arguments to resolve HRA disputes.

Arguments from precedents are most commonly deployed when the Court is seeking to overrule its own decisions. In Secretary of State for the Home Department v. $A F^{37}$, the House of Lords had to consider whether the right to a fair trial as protected under Article 6 of the Convention would be violated if the case made against a person in a control-order proceeding was based solely or to a decisive degree on closed materials that were not disclosed to him. Previously, a majority of the House of Lords in Secretary of State for the Home Department v. $M B^{38}$ had accepted that Article 6 did not impose such a per se rule against the use of such closed materials, and it would be up to the trial judge to decide whether the requirements of fair trial were met in the circumstances of any particular control-order proceeding. Nevertheless, since $M B$, the Grand Chamber of the ECHR in $A$ v. United Kingdom ${ }^{39}$ had ruled emphatically that the requirements of fair trial could never be satisfied in such circumstances, regardless of how cogent the case based on the closed materials might be. As such, Lord Phillips, who wrote the leading judgment in $A F$ opined as follows: 'That is why the clear terms of the judgment in $A$ v. United Kingdom resolve the issue raised in these appeals. ${ }^{40}$ Lord Rodger echoed the same views, but with more rhetorical flourish:

Even though we are dealing with rights under a United Kingdom statute, in reality, we have no choice: Argentoratum locutum iudicium finitum -

\footnotetext{
${ }^{33}$ B Cardozo The Nature of the Judicial Process (New Haven: Yale University Press, 1921) p 149.

${ }^{34}$ R v . Secretary of State for the Environment, Transport and the Regions, ex p Alconbury [2001] 2 AC 295 (HL) [26] (Lord Slynn).

${ }^{35} R$ v. Horncastle [2010] 2 AC 373 [11] (Lord Phillips).

${ }^{36}$ For a fuller discussion of the 'mirror principle', see R Clayton QC 'Smoke and Mirrors: the Human Rights Act and the impact of Strasbourg case law' [2012] PL 639 and Sir P Sales 'Strasbourg Jurisprudence and the Human Rights Act: A Response to Lord Irvine' [2012] PL 253.

${ }^{37}$ [2010] 2 AC 269 (HL).

38 [2008] 1 AC 440 (HL).

39 (2009) 49 EHRR 29.

${ }^{40}$ Secretary of State for the Home Department v . AF (n 37) [64].
} 
Strasbourg has spoken, the case is closed. ${ }^{41}$

More commonly, however, the Court would not be faced with an ECHR precedent that is directly on point with the issues before it. When confronted with an unsettled question, the task before the Court is to reason analogically from past precedents by identifying ways in which these decisions are "similar to or different from each other and the question ${ }^{42}$ before it, and developing a legal principle that captures the similarities and differences that are deemed important.

Such analogical reasoning from precedents was displayed by the House of Lords in $R$ (Purdy) v. Director of Public Prosecutions ${ }^{43}$. In that case, the Court unanimously held that the DPP had violated the applicant's Convention right, under Article 8, to respect for her private life, so far as he had refused to disclose factors he would take into account in deciding whether to prosecute her husband for complicity in suicide if he had assisted her death in a foreign country where assisted suicide was legal. It is noteworthy that the ECHR had decided in Pretty v. United Kingdom ${ }^{44}$ that Britain's ban on assisted suicide was a proportionate limitation on the Article 8 right; but, interestingly, both Baroness Hale and Lord Brown drew from the ECHR's arguments in Pretty in support of their conclusions. For Baroness Hale, she noted that the ECHR upheld the ban on the basis it provides 'for a system of enforcement and adjudication which allows due regard to be given in each particular case to the public interest; ${ }^{45}$ and since the justification of such a ban depended upon the flexibility of its operation, her Lordship opined that the ban could not be in accordance with law under Article 8(2) unless 'there is greater clarity about the factors which the Director of Public Prosecutions and his subordinates will take into account in making their decisions. ${ }^{46}$ Similarly, Lord Brown argued that, implicit in the ECHR reasoning in Pretty, a prosecution in certain circumstances would actually be inappropriate; and therefore, a blanket ban, without more, would not be in accordance with law unless the official policy for or against prosecution was promulgated. ${ }^{47}$

In the same vein, Lord Kerr, in his dissenting opinion in Ambrose v. Harris ${ }^{48}$, attempted to reason analogically from prior ECHR precedents. On the facts, the majority held that the Grand Chamber of the ECHR decision in Salduz v. Turkey $^{49}$ had not expressly mandated that an accused be given the right of access to a lawyer, prior to police questioning, before he or she was taken into police custody. In disagreement, Lord Kerr argued that a suspect could be equally vulnerable at any juncture when evidence that was potentially inculpatory was being obtained, and the focus of the ECHR's concern in Salduz was on the circumstances in which the

\footnotetext{
${ }^{41}$ Ibid [98].

42 E Sherwin ‘A Defence of Analogical Reasoning in Law' (1999) 66U. Chi. L.Rev. 1179, 1179.

43 [2010] 1 AC 345.

44 (2002) 35 EHRR 1.

${ }^{45} R$ (Purdy) v . Director of Public Prosecutions [2010] 1 AC 345 [76].

${ }^{46}$ Ibid [63]-[64].

${ }^{47}$ Ibid [74]-[75].

${ }^{48}$ [2011] 1 WLR 2435 (UKSC).

${ }^{49}$ (2009) 49 EHRR 19.
} 
questionings could produce self-incriminating statements. ${ }^{50}$ Therefore, for Lord Kerr, Salduz would require the State to inform a suspect of his or her right to legal representation, even if he or she was not in police custody, as long as those questions put to him or her were capable of producing inculpatory evidence. ${ }^{51}$

In essence, analogical reasoning is, in itself, a form of precedential argument, so far as judges are seeking to construct legal rules that conform to a body of existing decisions and reconcile new developments with past ones. As observed by Professor Richard Fallon, prior judicial decisions form 'a patchwork into which a current problem must be fitted through ${ }^{, 52}$ a combination of analytical and analogical reasoning.

\section{(d) Consequentialist Arguments}

Consequentialist arguments are legal arguments deployed by the Court that take into account the costs and benefits of a specific rule, and also the political and practical consequences of ruling in any particular way. In other words, consequentialist argumentation is more than just a 'law and economics' approach to judicial balancing; it also takes into account the institutional disadvantages of the judicial forum and the conditions of epistemic uncertainty that judges face during deliberation, and this underscores the role for judicial deference in constitutional adjudication. The proportionality analysis adopted by the UK judiciary and many other common law courts when they review the necessity of legislative limitations on rights is one such consequentialist interpretive device. A classic formulation of what the Court asks when it applies the proportionality doctrine is as follows:

Whether: (i) the legislative objective is sufficiently important to justify limiting a fundamental right; (ii) the measures designed to meet the legislative objective are rationally connected to it; and (iii) the means used to impair the right or freedom are no more than is necessary to accomplish the objective. ${ }^{53}$

This interpretive device, at one level, involves a form of cost-benefit analysis as judges have to weigh the importance of various statutory goals against the severity of any rights-derogations. In so doing, judges often acknowledge that they may need 'additional background information tending to show, for instance, the likely practical impact of the statutory measure ${ }^{, 54}$ under challenge.

A good illustration of this type of consequentialist argument at play would be the Supreme Court's decision in $R$ ( $F \&$ Thompson) v. Secretary of State for the Home Department. ${ }^{55}$ In that case, the Court had to consider whether the statutory imposition on all sexual offenders, who were sentenced to 30 months' imprisonment or more, a

\footnotetext{
${ }^{50}$ Ambrose v . Harris (n 48) [137]-[138].

${ }^{51}$ Ambrose v. Harris (n 48) [146].

${ }^{52} \mathrm{R}$ Fallon Jr 'A Constructivist Coherence Theory of Constitutional Interpretation' (1987) 100 Harvard L.Rev. 1189, 1202.

${ }^{53}$ De Freitas v. Permanent Secretary of Ministry of Agriculture, Fisheries, Lands and Housing [1999] 1 AC 69; $R$ v. Secretary of State for the Home Department, ex p Daly [2001] 2 AC 532.

${ }^{54}$ Wilson v. First County Trust Ltd (No 2) [2003] 1 AC 816 [63].

55 [2011] 1 AC 331(UKSC).
} 
life-long requirement, without the right of review, to notify the police of where they were living and their travel plans, violated the offenders' Convention right to respect for their private lives. The Court eventually ruled that this legislative measure was too disproportionate as the imposition of the notification requirement was for life and without review, and the government had advanced no evidence before the courts to demonstrate that it was impossible to identify some sexual offenders who posed no significant risk of re-offending; the fact that many other countries like Canada, France, Ireland, and the United States all provided for such review further suggested that such a review exercise was not impracticable. ${ }^{56}$

But the consequentialist argument is also more than just a cost-benefit analysis. In applying the proportionality analysis, however, scholars have observed that courts face two general limitations when they deploy such consequentialist arguments. First, it is recognized that, vis-à-vis the legislature, the judiciary lacks democratic legitimacy. ${ }^{57}$ Since judges are less accountable to the electorate, the judicial forum may not be the most appropriate institution to resolve societal disputes concerning the contested application of competing rights. Second, on certain issues concerning resource allocation, fiscal planning, and national security, it is generally recognized that the political branches of government have more information, experience, and skills to assess the consequences of particular decisions and resolve such questions correctly, ${ }^{58}$ and therefore the judiciary may be institutionally less competent to decide whether the legislative/administrative limitations are constitutionally reasonable or right. These twin concerns about the court's intrinsic limitations have led to a demand for judicial deference in public law where courts are encouraged to assign weight to the primary determinations of the political branches and exercise restraint when they review legislative/administrative decisions. ${ }^{59}$

While Professor Trevor Allan does not reject the idea of judicial deference per se and believes that courts may take into account 'questions of constitutional propriety and judicial restraint [that] are internal to the ordinary judicial process ${ }^{, 60}$, he refutes Dr Aileen Kavanagh's suggestion that deference may also be defended on prudential grounds where courts may consider whether

a particular judicial decision would produce a backlash in society; whether society is ready for the legal change; whether it might be counterproductive to introduce it at this particular time; and whether the elected branches of government would than move to curtail the powers of the courts as a result. ${ }^{61}$

According to him, such prudential concerns have no place in any judicial

\footnotetext{
${ }^{56} R$ (F \& Thompson) v. Secretary of State for the Home Department [2010] UKSC 17 [56].

${ }^{57} \mathrm{~J}$ Waldron Law and Disagreement (Oxford: Clarendon Press, 1st edn, 2001).

${ }^{58}$ A Kavanagh 'Deference or Defiance? The Limits of the Judicial Role in Constitutional Adjudication' in G Huscroft (ed) Expounding the Constitution: Essays in Constitutional Theory (Cambridge: Cambridge University Press, 2008) pp 193-199.

${ }^{59}$ A Kavanagh 'Defending deference in public law and constitutional theory' (2010) 126 LQR 222, 223.

${ }^{60} \mathrm{~T}$ Allan 'Judicial Deference and Judicial Review: Legal Doctrine and Legal Theory' (2011) 127 LQR 96, 100 .

${ }^{61}$ Kavanagh, above n 58, p 205.
} 
determination of rights as judicial moves to assuage a hostile legislature is a form of subterfuge, which is inconsistent with the fundamental judicial duty to impartially administer justice in each case according to law. ${ }^{62}$

Nevertheless, this view is premised on an assumption that judges are infallible in their moral deliberations; whenever judges unwillingly submit to legislative whims, they must be consciously subverting the rule of law. But if we take the view that judges are capable of committing moral blunders, and that they are conscious of their own fallibilities, we may agree that judges, when deciding upon highly contested moral dilemmas, should take into account any strongly held views of the legislature (or the electorate), as it is equally plausible that in the long run these legislative views may prove to be the normatively correct ones.

Consequentialist arguments that reflect the Court's unease with its lack of democratic credentials were most evidently displayed in the House of Lords decision in $R$ (Pretty) v. Director of Public Prosecutions. ${ }^{63}$ On the facts, the claimant, a physically incapacitated, terminally ill person, argued that DPP's refusal to give an undertaking not to prosecute her husband for assisting her suicide overseas was a violation of her right to life and privacy. The House of Lords unanimously rejected her claim and, in particular, Lord Hope opined as follows:

In the present uncertain climate of public opinion, where there is no consensus in favour of assisted suicide and there are powerful religious and ethical arguments to the contrary, any change in the law which would make assisted suicide generally acceptable is best seen as a matter for Parliament. ${ }^{64}$

Such acknowledgement that adjudication must at times be permeable to public opinion certainly poses a challenge to traditional views that judges merely apply determinate rules impartially. ${ }^{65}$ Nevertheless, one must note that while courts are granted a constitutional mandate to interpret rights, and they should discharge this democratic duty faithfully, there may be exceptional cases in which a particular law reform may create widespread upheaval in society that courts, in view of inherent epistemic moral uncertainty associated with judicial law-making, may prefer to secure some consensus or support from the elected branches of government before they so act. This should not be viewed as a form of judicial abdication as Professor Jeffrey Jowell has argued, ${ }^{66}$ but instead as a candid recognition that judges, like legislators, are fallible at moral reasoning, and they may prefer not to exclude the ordinary political process from deliberating on important constitutional issues. Therefore, to this extent, the prudential concerns dovetail with the argument for judicial deference on the ground of the legislature's relative democratic legitimacy in resolving

\footnotetext{
${ }^{62}$ Allan, n 60, p 101.

${ }^{63}$ [2002] 1 AC 800.

${ }^{64} R$ (Pretty) v Director of Public Prosecutions [2002] 1 AC 800 [96].

${ }^{65}$ L Barmes ‘Adjudication and Public Opinion' (2002) 118 LQR 600, 600.

${ }^{66}$ J Jowell 'Judicial Deference and Human Rights: A Question of Competence' in P Craig and R Rawlings (eds) Law and Administration in Europe (Oxford: Oxford University Press, 2003) p 80.
} 
contested applications of competing rights/interests. ${ }^{67}$

Equally, the Court has deployed consequentialist arguments when it recognized the institutional disadvantages associated with its office when assessing national security claims. National security issues present the judiciary with an acute dilemma as, in carrying out their reviewing role, judges usually do not have all the secret information available to the primary decision makers and the stakes of some of these decisions are often very high. ${ }^{68}$ Deference is thus a rational, consequentialist response to this epistemic uncertainty.

Even as the House of Lords found against the government in A v. Secretary of State for the Home Department ${ }^{69}$, Baroness Hale had acknowledged as follows:

Assessing the strength of a general threat to the life of the nation is, or should be, within the expertise of the government and its advisers... It would be very surprising if the courts were better able to make that sort of judgment than the government. $^{70}$

It is thus unsurprising that the House of Lords in $R$ (Gillan) v. Metropolitan Police Commissioner ${ }^{71}$ upheld the police's statutory right to stop and search persons for articles connected to terrorism, even in the absence of reasonable suspicion. As Lord Scott observed, assessing whether the police should have such stop-and-search powers to combat terrorism require some information of the 'intelligence material on which the police and the Home Secretary relied when making their own assessment of that threat and of what should be done in response to it ${ }^{72}$, but the Court was not privy to such information and inevitably had to defer to the government's determination. ${ }^{73}$

\section{PART 2: DEFENDING 'MULTI-VALENCED' CONSTITUTIONAL INTERPRETATION}

As argued above, this 'multi-valenced' model of constitutional interpretation allows the Court to reason through different sources of legal arguments that draw from the text of the HRA, the history behind its enactment, the precedents built upon it, and the consequences or practical constraints of adopting competing interpretive positions.

These different strands or modalities of constitutional argumentation reasoning may

\footnotetext{
${ }^{67}$ See A Young 'In Defence of Due Deference' (2009) 72 MLR 554, 579. One must note that Allan himself has accepted that there are situations when judges should defer to the political branches of government on democratic grounds. See T Allan 'Human Rights and Judicial Review: A Critique of "Due Deference"، [2006] CLJ 672.

${ }^{68}$ A Kavanagh 'Judging the Judges under the Human Rights Act: Deference, Disillusionment and the "War on Terror"، [2009] PL 287, 301.

${ }^{69}$ [2005] 2 AC 68.

70 Ibid [226].

${ }^{71}$ [2006] 2 AC 307.

72 Ibid [62].

${ }^{73}$ One may however note that the ECHR, in Gillan \& Quinton v. United Kingdom (2010) 50 EHRR 45, subsequently ruled that these stop-and-search statutory powers were a disproportionate interference with the applicants' right to respect for their private lives, as protected under Art. 8 of the Convention.
} 
inevitably open this mode of legal reasoning to charges that it is inherently indeterminate and open to judicial manipulation, and it is to this criticism that I now turn. After all, different modalities may lead the Court to reach competing results, and judges will have an unconstrained choice to select the outcome they prefer. Such critics may prefer then for judges to privilege one or two types of constitutional arguments, for example textual or historical arguments, such that if these arguments point to a certain solution, its conclusion should strictly control the issue at hand.

At the outset, I will first concede that the multi-sourced interpretive approach may, in some cases, lead to divergent outcomes depending on the 'modality' of constitutional argumentation that the judges deem determinative. In Pinnockv. Manchester City Council $^{74}$, the Supreme Court eventually subordinated consequentialist arguments against the judicial review of individual applications for housing by local authorities tasked with the unenviable duty of distributing scarce resources efficiently to the precedential argument following the ECHR's insistence ${ }^{75}$ that Article 8 of the Convention (the right to respect for one's private and family life) required a tenant to have an opportunity to have the courts determine whether his or her eviction is proportionate.

In the same vein, in Tariq v. Home Office ${ }^{76}$, the majority on the Supreme Court was persuaded by consequentialist arguments in favour of excluding the claimant, a former immigration officer, from certain aspects of his employment tribunal proceedings on grounds of national security concerns, and held that this 'closed procedure' was not a violation of his Convention-protected right to a fair trial. As opined by Lord Hope:

In this case the individual is not faced with criminal proceedings against him or with severe restrictions on personal liberty. This is a civil claim and the question is whether Mr Tariq is entitled to damages... But the Home Office says that it cannot defend the claim in open proceedings as, for understandable reasons, it cannot reveal how security vetting was done in his case. That conclusion is unavoidable, given the nature of the work Mr Tariq was employed to do. ${ }^{77}$

On the other hand, Lord Kerr, in his dissenting opinion, preferred to emphasize the historical arguments for providing the claimant with access to the withheld material, as the "right to know and effectively challenge the opposing case has long been recognized by the common law as a fundamental feature of the judicial process. ${ }^{78}$

While different types of constitutional argument may lead to divergent constitutional outcomes in some cases, one must note that any judicial reliance on a singular

\footnotetext{
${ }_{75}^{74}[2011] 2$ AC 104.

${ }^{75}$ See Connors v. United Kingdom (2005) 40 EHRR 9 and McCann v. United Kingdom [2008] 2 FLR 899.

${ }^{76}[2012] 1$ AC 452.

${ }^{77}$ Ibid [81].

${ }^{78}$ Ibid [102].
} 
interpretive methodology will not solve this problem.

Texualists may appeal to the statutory language of the HRA, for the authority of the text rests on the normative appeal of a formal, legally adopted law. ${ }^{79}$ But the HRA, like most human rights instruments, enshrines abstract, open-textured rights that are often open to a multitude of interpretations in specific contexts, and textualism alone cannot resolve this interpretive conundrum. Originalists may prize historical arguments in constitutional adjudication such that judicial review can become more democratic by virtue of their connection to the past judgments of the HRA framers; and consequently, judicial discretion can also be fettered by this turn to history. ${ }^{80}$ Yet, any attempts to shackle the HRA to the framers' original specific application of the text at the time of enactment may indeed be inconsistent with Parliament's express intent of allowing the UK judges to 'contribute to this dynamic and evolving interpretation of the Convention' ${ }^{, 1}$ that reflects 'changing social attitudes and changes in the circumstances of society. ${ }^{82}$ So far as the HRA was meant to incorporate the Convention within domestic law, the precedents of the ECHR will provide immense insights to the UK courts. But the British judges can never be legally bound by these precedential arguments, for that would fly in the face of the express statutory language of the HRA that merely mandates them to 'take into account' ${ }^{83}$ these European judgments. Consequentialist arguments are very helpful when courts are crafting doctrinal rules to implement various human rights norms. One such example is the proportionality doctrine, a ubiquitous interpretive device where judges have to weigh the institutional competence of the courts to intervene in polycentric issues against the severity of any rights-derogations, and adopt a context-specific variable intensity of review over the legislative actions. ${ }^{84}$ But if judges were to consider consequentialist arguments alone, without more, they may be perceived to be engaging in lawless judging and usurping the legislative prerogatives on policymaking. ${ }^{85}$ Ultimately, as we observe above, no singular interpretive argument can be relied upon exclusively to resolve all HRA disputes.

Furthermore, critics that consider 'multi-valenced' interpretation indeterminate and uncertain because of the presence of 'cross-modal' conflicts ${ }^{86}$ may often neglect the fact that 'intra-modal' conflicts ${ }^{87}$ can also take place such that, even within the same interpretive medium, judges may have different views on the right outcome.

\footnotetext{
79 Jackson, n 9.

${ }^{80}$ R Bork The Tempting of America: The Political Seduction of the Law (New York: The Free Press, 1990) pp 143-160; Scalia, n 5, p 17.

81 The Home Department, Rights Brought Home: The Human Rights Bill (White Paper, Cm 3782, 1997) para 2.5 .

${ }^{82}$ Ibid.

${ }^{83}$ Human Rights Act 1998, section 2.

${ }^{84} \mathrm{~J}$ Rivers 'Proportionality and variable intensity of Review' [2006] CLJ 174.

${ }^{85}$ TS Schrock and RC Welsh 'Reconsidering the Constitutional Common Law' (1978) Harvard L.Rev. 1117.

${ }^{86}$ Balkin and Levinson, n 11, p 1796.

${ }^{87}$ Ibid.
} 
In $R$ v. Lambert ${ }^{88}$, as discussed earlier, the majority on the House of Lords applied textual arguments in reading section 22(4) against section 7(1)(b), and concluded that the HRA could not apply retrospectively to appeals against convictions that were secured in trials that predated the coming into effect of the HRA. Yet, it is noteworthy that Lord Steyn, in dissent, also applied textual arguments but only to reach the opposite conclusion. ${ }^{89}$ According to his Lordship, the determinative HRA provision in question was section 6(1), which provides that it is unlawful for a public authority, which includes the House of Lords, to act in a way which is incompatible with a Convention right. Since the appeal was heard before the House of Lords after the HRA had come into effect, Lord Steyn argued that section 6 would bind the conduct of the Law Lords. As he observed:

There is also nothing in section 7 which expressly or by necessary implication qualifies the ordinary and plain effect of section 6(1)... I agree with Clayton $\&$ Tomlinson... that 'the effect of Section 22(4) is obscure'... The language of the statute points in one direction only: the House may not act unlawfully by upholding a conviction which was obtained in breach of a Convention right. It will be observed that this interpretation reads nothing into section $6(1) \ldots$ it simply gives effect to the obvious meaning of plain words. ${ }^{90}$

In the same vein, in $R$ (Wellington) v. Secretary of State for the Home Department ${ }^{91}$, the House of Lords were divided on whether, for the purposes of Article 3 of the Convention, the test to determine what constituted 'inhuman or degrading treatment or punishment' was the same when one was considering the likely fate that an individual, whose extradition was being sought, would face in the requesting country as when one was considering what constituted inhuman treatment in a purely domestic context. But one must note that both the majority and the dissent applied precedential arguments for their conclusions. The majority ${ }^{92}$ preferred a 'relativist' approach to what constituted inhuman treatment as this seemed to be sanctioned by Strasbourg in Soering v. United Kingdom. ${ }^{93}$ The minority ${ }^{94}$ argued for an 'absolutist' approach as that seemed to them to be the legal position after Chahalv. United Kingdom. ${ }^{95}$

Similarly, in $R$ (Aguilar Quila) v. Secretary of State for the Home Department ${ }^{96}$, a majority of the Supreme Court invalidated an immigration rule that required both the UK-based sponsor and his or her overseas-based spouse to be over the age of

\footnotetext{
${ }^{88}$ [2002] 2 AC 545.

${ }^{89}$ For a critique of Lord Steyn's arguments, see D Beyleveld, R Kirkham and D Townend 'Which Presumption? A Critique of the House of Lords' Reasoning on Retrospectivity and the Human Rights Act' (2002) LS 185, 199-200.

${ }^{90}$ Lambert (n 15) [28].

91 [2009] 1 AC 335.

92 Ibid [30] (Lord Hoffmann); [50]-[51] (Baroness Hale); [57]-[58] (Lord Carswell).

${ }^{93}$ (1989) 11 EHRR 439.

${ }^{94} R$ (Wellington) (n 91) [2009] 1 AC 335, [85] (Lord Brown); [40] (Lord Scott).

95 (1997) 23 EHRR 413.

96 [2012] 1 AC 621.
} 
$21,{ }^{97}$ before the former could sponsor the latter's resettlement in the United Kingdom. It was noteworthy that both the majority and the dissent applied consequentialist arguments in determining whether this legislative measure was a proportionate limitation on the applicant's right to marry. For the majority, the measure was disproportionate as this rule would interfere with more entirely voluntary marriages than it would deter or delay forced marriages, the primary legislative goal. ${ }^{98}$ Lord Brown, in dissent, argued that the majority's proportionality analysis was misconceived as the comparison between the enormity of suffering within forced marriages and the disruption to innocent couples who had to wait up to three years before they could live together in the United Kingdom was one essentially for elected politicians and not judges to make. ${ }^{99}$

In the foregoing analysis, I have sought to illustrate that 'intra-modal' conflicts can be as equally perplexing as 'cross-modal' ones. Courts are routinely faced with conflicting precedents, contrasting consequentialist considerations, and/or clashing textual arguments. Therefore, any reliance on a fixed, singular modality will not make the interpretive task of the courts any easier or less discretionary.

Finally, the use of this 'multi-valenced' approach may indeed help resolve 'intramodal' conflicts within a particular medium. For example, where there is contrasting textual arguments, judges may turn to precedential and/or consequentialist arguments to see whether the other arguments can break the impasse by pointing in any particular direction that help resolve the interpretive conundrum. In Wilson v. First County Trust Ltd ${ }^{100}$, the House of Lords had to decide, inter alia, whether a contractual agreement governed by the Consumer Credit Act, which had been entered into before the implementation of the HRA, could none the less be subjected to the provisions of the HRA. One may note that the Law Lords therein were confronted with competing textual arguments at play. On one hand, the remedial interpretive obligation of section 3 of the HRA applies to primary and secondary legislation 'whenever enacted'; but on the other hand, there exists an accepted canon of statutory construction which provides that legislation is presumed not to operate retrospectively. ${ }^{101}$ In the end, the Law Lords turned to consequentialist arguments to resolve this textual gridlock. As opined by Lord Nicholls who wrote the leading judgment:

Considerable difficulties, however, might arise if the new interpretation of legislation, consequent on an application of s3, were always to apply to pre[Human Rights] Act events. It would mean that parties' rights under existing legislation in respect of a transaction completed before the Act came into force could be changed overnight, to the benefit or one party and the prejudice of the other. This change, moreover, would operate capriciously, with the

\footnotetext{
${ }^{97}$ Prior to 27 November 2008, both spouses had to be at least 18 years of age.

${ }^{98} R$ (Aguilar Quila) (n 96) [58] (Lord Wilson); [74] (Lady Hale).

${ }^{99}$ Ibid [91].

${ }^{100}$ [2004] 1 AC 816.

101 PB Maxwell On the Interpretation of Statutes (London: William Maxwell \& Sons, 12th edn, 1969) p 215.
} 
outcome depending on whether the parties' rights were determined by a court before or after 2 October $2000 \ldots$.. [D]ifferent considerations apply to post-Act criminal trials in respect of pre-Act happenings. The prosecution does not have an accrued or vested right in any relevant sense. ${ }^{102}$

In the same vein, where the text of the HRA is silent on how a constitutional issue should be resolved, precedential and consequentialist arguments may dovetail with each other and point in the same interpretive direction. In $M$ v. Secretary of State for Work and Pension ${ }^{103}$, a parent, who lived with her same-sex partner, challenged her child support contribution as it was greater than it would have been if she were in a heterosexual relationship, but a majority of the House of Lords refused to deem the impugned statutory measure, inter alia, a violation of her right to respect for family life. First, the majority noted that the ECHR had not recognized the relationship between same-sex couples as constituting family life within the Convention; ${ }^{104}$ and secondly, the discriminatory measure had already been removed by the Civil Partnerships Act, and the majority was thus reluctant to 'stigmatise as unjustifiably discriminatory a regime which, given the size of the overall task and the need to recruit the support of the public, could scarcely have been reformed sooner.' ${ }^{105}$ Therein, arguments from precedent dovetailed with the consequentialist argument for judicial deference on the basis of Parliament's comparative democratic legitimacy in resolving contested application of rights.

\section{CONCLUSION}

As observed above, this four-fold 'multi-valenced' constitutionalism is characteristic of the Court's current interpretive approach during HRA adjudication. The judicial focus on the different modalties of text, history, precedents, and consequences may shift according to the constitutional issue at hand, and new modalities may emerge over time; but in tandem, they provide an overarching interpretive framework for the Court to arrive at a reasoned legal result.

Certainly, the multiplicity of legal argumentations may provide for reasonable disagreements within this legal discourse. But as Professor Phillip Bobbitt has argued, recourse to a singular interpretive source is not a viable alternative:

A single modality cannot be both comprehensive and determinate. If it is determinate - does not generate contradictory outcomes - then there will be some cases it cannot decide... If the scheme is comprehensive, it will generate inconsistent outcomes. ${ }^{106}$

Moreover, so far as the Court is open to considering a range of perspectives on an interpretive question, its quest to find a coherent interpretive account that is consistent

\footnotetext{
${ }^{102}$ Wilson (n 100) [18], [21].

103 [2006] AC 91.

104 Mata Estevez v. Spain App No 56501/00 (10 May 2001, unreported).

${ }^{105} M$ v. Secretary of State (n 103) [6] (Lord Nicholls).

${ }^{106}$ Bobbitt, n 4, p 30.
} 
with these varying modalities may provide some constraint on its exercise of discretion. Though it may be rare for the four modalities to prescribe a uniform result, the interactions between the different types of interpretive arguments may often point, on balance, in a particular interpretive direction.

Constitutional interpretation, as Professor Vicki Jackson has observed, relies on 'judgment, not algorithm; it requires judicial self-discipline, located within a particular community's interpretive traditions, and [is] based on an appreciation for the limited but important role of judges in a democracy ${ }^{107}$. In seeking harmony between the settled expectations of the past and the evolving needs of a changing nation, the Court has embraced this multiplicity of constitutional arguments that seeks to accommodate and reconcile the divergent theories of constitutional justice that reflect the diversity in society. For the HRA to endure, the Court must continue to weave a legal narrative that conjoins the best in statecraft and adjudication, for that is the cardinal feature of Britain's constitutional practice.

${ }^{107}$ Jackson, n 9, p 637. 